\title{
Primary school students' barriers on learning Javanese Language : a case study in Central Java, Indonesia
}

\author{
Linda Nurmasari $^{1}$, Slamet Subiyantoro ${ }^{1}$, Siti Sutarmi Fadhilah ${ }^{1}$ \\ ${ }^{1}$ Universitas Sebelas Maret, Jl. Ir. Sutami 36A Kentingan Surakarta, 57126, Indonesia \\ Email: allynce89@gmail.com
}

\begin{abstract}
Teachers in primary school expressed concern about students' lack of understanding of Javanese language, especially in the use of Javanese language levels. Although Javanese language is their mother tongue, students did not have many opportunities to learn Javanese language well. This study aims to describe students' barriers on learning Javanese Language. The study belongs to descriptive qualitative research. Ninety eight students, seven teachers, and two principals from five different schools involved in the study. The data were collected using semi-structured interviews and observation. Interactive analysis was used to analyze data while in the field. Triangulation of data sources and techniques were used to test the credibility of the data. Results of the study demonstrate that there are lots barriers on learning Javanese language for students such as: (1) language habits in family, school, and neighbourhood, (2) Javanese language complexity, (3) lack of competent Javanese language teachers, (4) limited hours of Javanese language lessons, and (5) lack of media and learning resources that can support on learning Javanese language. It is important that schools, parents, communities, and governments should work together to overcome the barriers so that students do not lose their identity.
\end{abstract}

Keywords: Javanese language; primary school; students’ barrier 


\section{INTRODUCTION}

Javanese is a language used by Javanese ethnic that spreads almost in all parts of Indonesia. Java is ranked 11th in the world for the largest number of speakers, $75,500,800$ speakers [1]. Javanese is often juxtaposed with Japanese because they both have language levels [2]. In the Javanese language there are two varieties of language, namely ngoko and krama. Ngoko is a language used in a conversation among people who are familiar. While krama is a more subtle language that aims to respect the other person. Krama is used to communicate with older people, people of higher social status, or persons of the same age but who are not familiar or newly acquainted.

People in Sragen regency use Javanese language in their daily life. But just like in other parts of Indonesia, the use of Javanese in formal situations is very rare. This is often happened because people are afraid in using the right language. Actually this phenomenon has long been happening. Before the second world war, Javanese from the upper classes used to switch to Malay or Dutch to avoid using their Mother tongue and to free themselves from language politeness [3].

Rapid language changes occur both in Java and throughout Indonesia more widely. Now, young families do not apply the Javanese language level at home anymore. Based on interviews with students, $71.43 \%$ of students stated that at home they use Javanese ngoko or sometimes Indonesian to communicate with parents. They rarely hear people conversing with krama language in the neighborhood where they live. If the previous generation has their mother tongue as a regional language, now many children are using Indonesian as their mother tongue [4].

The decline existence of local languages influenced by Indonesian language dominance in daily life, the popularity of foreign languages, and changes in socioeconomic conditions [5]. The need to maintain the existence of local languages, including Javanese language become very urgent. To preserve Javanese language is not enough only through learning process in school. The environment also has a profound effect on the development of students' language. However, learning time in schools should be utilized optimally so that students can learn well because there are a lot of Javanese subject matter that they will not get in the daily interaction. With this research, the government is expected to pay more attention to Javanese language as one of local wealth and national identity that must be preserved.

\section{METHOD}

This research is a descriptive qualitative study type case study. Data were collected using interview technique and observation. Semi-structured interview techniques are used to obtain as much and profound data as possible about the barriers facing by students in learning Javanese language. Observations were made during the learning process to observe the interaction between teachers and students and students with students during the learning process of Javanese language. It is also to observe the language used by students both inside and outside the lesson. Interactive analysis of Miles and Huberman models is used to analyze data in the field. Triangulation 
techniques are used to check the credibility of the data. Interviews and observations were analyzed to determine whether the data obtained were valid.

Participants in this study were ninety eight students, seven teachers, and two principals from five different schools. Four schools are state schools, while the other one is an integrated Islamic primary school.

\section{FINDINGS}

To determine the barriers faced by students in learning Javanese language, respondents are asked to give their views on this issue and below is the views of respondents.

\section{TABLE I. PRINCIPALS’ VIEWS OF THE BARRIERS FACED BY STUDENTS IN LEARNING} JAVANESE LANGUAGE

\begin{tabular}{|l|}
\hline Students are not used to learning Javanese language \\
\hline Lack of Javanese lesson hours \\
\hline Less supportive environment for good and correct Javanese, both at home and at school \\
\hline The existing Javanese book does not fit the school's needs \\
\hline Difficult to apply the Javanese language in a formal situation \\
\hline Difficult to find a competent Javanese teacher \\
\hline Some parents argue that it is more important to learn English than Javanese \\
\hline
\end{tabular}

TABLE II. TEACHERS' VIEWS OF THE BARRIERS FACED BY STUDENTS IN LEARNING JAVANESE LANGUAGE

\begin{tabular}{|l|}
\hline Students are less used to Javanese \\
\hline Students are less interested in Javanese language \\
\hline Students lack understanding of Javanese vocabulary \\
\hline There is no teacher working group for Javanese language teachers \\
\hline Students rarely learn Javanese language \\
\hline Lack of Javanese lesson hours \\
\hline Difficult to find media lessons that can support Javanese language lesson \\
\hline
\end{tabular}

TABLE III. STUDENTS’ VIEWS OF THE BARRIERS THEY HAVE FACED IN LEARNING JAVANESE LANGUAGE

Javanese language is a very difficult lesson

Many elusive vocabulary

Difficult to change Javanese ngoko to krama

Javanese lessons are only once a week

The subject matter of Javanese is very complex

From the table above we can see that there are a lot of barriers faced by students in learning Javanese language. Although Javanese is the native language of Sragen regency, students rarely use Javanese especially on the learning process in class so that their skills in Javanese are also very low. The main difficulty that students face is the use of the Javanese variety of manners, as it is expressed by a first grade student: 
'Krama language is difficult, because I do not know what the krama of hands, feet, hair, and others.'

This is reinforced by the opinion of a first grade teacher at another school who tells that:

'I saw the children of first grade begin to recognize the variety of manners in school like the krama of body organs. They will know if the teacher says irung (nose in ngoko) but when the teacher says grana (nose in krama) they were getting confused. The outcomes of this lesson are also less encouraging because they only learn it at school without practicing it at homes when they talk to their parents.'

Not only the low-grade students who complained about the difficulty of using Javanese, a fourth-grader when was asked about the difficulty in learning Javanese, he replied:

'Yes, there is. The difficulty is I can not distinguish between ngoko language and krama language.'

Actually, there have been efforts to civilize the Javanese language, for example by the release of the Regent's Instruction Letter No: 431/1324/023/2014 on the Use of Javanese Language For Oral Communication in Sragen Regency Government which is a follow-up of the Central Java Governor Circular on October 7, 2014. The whole range of employees in the Government of Sragen Regency should use the Javanese language every Thursday, including teachers and students in primary school. However, the program hasn't worked. As expressed by a Principal:

'It used to be a Javanese-speaking on Thursdays. But less intense because it was difficult to apply it so eventually returned to Indonesian language. It used only one semester but it can not survive because it is difficult. It was only used at the time of the ceremony, but beyond it returned to their respective abilities.'

Based on the results of data analysis, there are five main barriers for students in learning Javanese language which can be explained as follows.

\section{Language Habits in Family, School, and Neighboorhood}

Based on the results of interviews and observations, most of the students in Sragen regency use Javanese variety of ngoko at home. At school, when learning takes place the most commonly used language is Indonesian, while when the break time they often used the variety of ngoko language. A fourth grade teacher reveals:

'Children usually do not use Javanese krama but ngoko. If they used ngoko sometimes I scold, "Why do you use ngoko, just use Indonesian only if you can not 
speak Javanese." Often they use ngoko because their habit at home is use ngoko and Indonesian. So they do not know how to talk to parents in Javanese.'

A private school teacher who teaches Javanese in grades 4, 5, and 6 suggests:

'If in the village, maybe at home children using Javanese language ngoko, but if here more are using the Indonesian language so it is difficult to apply a good Javanese language culture. If at the time of learning Javanese language, I require children to use the Javanese language. For example if they want to go to the bathroom, I require them to ask permission with Javanese krama.'

A fifth grade teacher at another school also tried to apply the effort and he told the following:

'In the learning hours of Javanese language, I always use the Javanese language introduction. Children are also required to inquire, communicate with their friends, permit to the bathroom with good and correct Javanese language. Being interesting because every hour of Javanese lessons, no students asks permission to the bathroom and the situation in class is so quiet.'

Associated with the habit of this language, the teacher was difficult or even impossible regardless of the use of Javanese language when teaching. The observations in the third grade in one of the primary school showed interesting findings during a Javanese lesson. Here is an example of dialogue between teacher and students:

Teacher : 'Bukaken bukumu halaman 33! Nang kono ana conto geguritan.' (Open your book on page 33! There's an example of geguritan.)

Student : 'Bu, geguritan niku apa to?' Mom, what is geguritan?

Teacher : 'Geguritan iku puisi berbahasa Jawa.' Geguritan is a Javanese poetry.

From the brief dialogue above it appears that when the student is asking and using Javanese variety of ngoko language, that is actually less polite. Then the teacher replied with a mixed language between Javanese and Indonesian. When it was asked, the teacher said that the definition would be the most easily understood by the students. If the teacher explains too long in Javanese language maybe they will not understand.

\section{Javanese Language Complexity}

Javanese language is known as a very complex language. First, there is a level or stratification of language. Javanese linguists simplify the Javanese language level into four, namely Ngoko lugu, Ngoko alus, krama lumrah, and krama alus [3]. These levels are the levels considered to be current. 
Second, there are many words that have synonyms (dasanama). For example the word "sun" in Javanese can be called srengenge, arka, aruna, bagaskara, bagaspati, baskara, diwangkara, pratanggapi, raditya, radite, rawi, surya, and also we. Although synonyms learned in primary schools are usually only two or three words which are commonly used words in everyday life, but this is quite difficult for students.

Thirdly, there are many words with the same spelling but are read differently and have different meanings (homograph). This was revealed by a teacher in the fifth grade:

'Javanese language is difficult. When asked to read, most students are wrong in their pronunciation. For example, the word kèndêl (silent) is read kêndêl (brave). Once also lêmpêr (food made from sticky rice) is read lèmpèr (plate of stone or ground to grind chili and so on). They are less able to relate to existing reading contexts'

Fourth, knowledge in Javanese is very broad. For each name of animal child there is its own name, as an example a chick called kuthuk, piglets called gembluk, bull child called wareng, crocodile child called rete, duckling called meri, and many more. Grains, fruits when young, leaves, flowers in a tree, the number of boys and girls and their order in family, all have their own names in Javanese.

\section{Lack of Competent Javanese Language Teachers}

Javanese teachers who teach in primary school in Sragen regency do not come from graduates of Javanese language study program. The teachers are graduated from the Primary School Teacher Education Program which teaches all subjects, except Religion and Physical Education. Even in many schools Javanese language subjects are taught by a busy Principal and can not focus on teaching well. There are also Javanese language teachers who come from graduates of Islamic Religious Education which is certainly not appropriate when teaching Javanese languange.

In one of the primary schools involved in this research, the second grade teacher came from Bandung, West Java, whose mother tongue is Sundanese. However, due to the limited teaching staff he still has to teach Javanese language. He said:

'Hard to teach Javanese language. I am afraid of being wrong so I use Indonesian language more often. I teach as much as I can just to keep the Javanese lessons so it is not empty.'

\section{Limited Hours of Javanese Language Lesson}

Javanese languages are included in local content subjects in some areas, particularly in Central Java, East Java and the Special Territory of Yogyakarta. Sragen region belongs to Central Java Province. Curriculum subjects Local Content for Public Primary / SDLB / MI and Private Schools in Central Java is based on Central Java Governor Decree Number 423.5/ 5/ 2010. Then for the implementation of Curriculum 2013 Local Content Javanese language in Central Java Province is based on Circular Letter of Head 
of Central Java Provincial Education Office No. 423.5 / 15322 Year 2014 [6]. One of the contents of this circular is to carry out the local content curriculum of Javanese Language is two hours a week.

Javanese language lessons that are only two hours a week become a barrier in itself, not only for students, but also for teachers in teaching Javanese. As expressed by a fourth grade teacher:

'Javanese is the main language in Central Java but it is only two hours a week. Sometimes the Javanese language schedule is on Friday or Saturday. Though the day is often used for Kelompok Kerja Guru (Teacher Working Group). Hence it is sometimes not taught. Especially for high classes are often upset if they do not get Javanese language. It would be better if the Javanese lesson hours added, for example four hours a week to be more profound.'

\section{Lack of Media and Learning Resources that Can Support on Learning Javanese Language}

So far not many media available for learning Javanese language. Javanese textbooks are available, but reading books or Javanese storybooks are still very rare. Javanese video or CD learning is also very rare. As expressed by a sixth grade teacher:

'We still lack the Javanese language media. There was a learning video that the subtitles is in Javanese, but the conversation was in English. I had to use that.'

The existing Javanese book according to one of the principals does not support the culture of unggah-ungguh (manners). A good effort has been done to overcome this. He states:

'For next year the board of teachers in my school has prepared our own books, although only for the first grade, because if buying from the publisher does not fit the needs of the school. So we synchronize between English, Arabic, and Javanese. For example for permission to the bathroom children must learn in three languages, English, Arabic, and Javanese at the same time.'

Not only at schools, in the environments around the students are almost no media that can support them to learn Javanese language. All shows on television use Indonesian or English, as well as posters or billboards along the way all speak Indonesian.

\section{DISCUSSION}

The findings above show that there are still many barriers for students in learning Javanese language. It is unfortunate if the next generation of this nation lost their 
identity. Javanese language is not included in the category of language that will be extinct. However, it can not be denied that the mastery of Javanese language and speech level to the younger generation is getting lower and lower. Many observers and linguists are of the opinion that Javanese languages are declining, so it is necessary to maintain or preserve the language [7. But these concerns have not been able to raise the nation's children to dig and re-empower the ancestral heritage [4].

Research on the use of Javanese in primary school has been done by Saddhono and Rohmadi [8]. However, the object of this study is very different from the research. The study examines the use of Javanese in class 1, 2, and 3 lessons whose students' mother tongue is in Surakarta, Central Java. The use of Javanese language can not be separated from other subjects for several reasons. The limited vocabulary of Indonesian language understood by students to be a barrier for students so that teachers use the Javanese language to facilitate students to understand the material. However, the results of this study show the opposite. Students in class I are better at speaking Indonesian than in Javanese. This is indicated by the results of interviews with students in classes 1,2 , and 3 who 85\% stated that the Javanese language is more difficult than the Indonesian language.

\section{CONCLUSION}

Many barriers faced by students in Javanese language lessons so that their Javanese language skills tend to be low. To overcome this all parties must work together, including schools, parents, communities, and governments to overcome the barriers that have been described above.

It is acknowledged by many parties that the Javanese language is very important in the character formation of children. This is because there is an element of respect for others with the use of appropriate language level. As the Javanese phrase is often expressed that it is impossible for a person to say harshly or cursed others when he uses krama language. Primary school age is a golden period for character formation of children so it is appropriate if Javanese language culture in primary school gets special attention from the government authorities.

\section{REFERENCE}

[1] $13^{\text {th }}$ Edition of the Ethnologue. (1999). Top 100 Languages by Population. Diakses di http://www.ethnologue.com/13/top100.html pada 21 Juni 2017.

[2] Rahayu, E. T. 2014. Comparison of Honorific Language in Javanese and Japanese Speech Community. International Journal on Studies in English Language and Literature (IJSELL), 2 (7), 140-146.

[3] Sumiyardana, K. (2010). Pergantian Makna dalam Bahasa Jawa Krama. Seminar Nasional Pemertahanan Bahasa Nusantara. Semarang: Magister Linguistik PPs UNDIP.

[4] Mbete, A. M. (2010). Strategi Pemertahanan Bahasa-bahasa Nusantara. Seminar Nasional Pemertahanan Bahasa Nusantara. Semarang: Magister Linguistik PPs UNDIP. 
[5] Gumilar, T. (2015). Regional Languages in Indonesian Educational System: a comparison study of Javanese, Sundanese and Dayak languages teaching programs. Investigationes Linguisticae, 13, 2942.

[6] Keputusan Gubernur Jawa Tengah Nomor 423.5/5/201 tentang Kurikulum Mata Pelajaran Muatan Lokal untuk Jenjang Pendidikan SD/SDLB/MI dan SMP/SMPLB/MTs Negeri dan Swasta Provinsi Jawa Tengah.

[7] Purwoko, H. (2010). Bahasa Jawa Semakin Melorot: Siapa Takut?. Seminar Nasional Pemertahanan Bahasa Nusantara. Semarang: Magister Linguistik PPs UNDIP.

[8] Saddhono, K. \& Rohmadi, M. (2014). A Sociolinguistics Study on the Use of the Javanese Language in the Learning Process in Primary Schools in Surakarta, Central Java, Indonesia. International Education Studies, 7 (6), 25-30.

[9] Surat Edaran Kepala Dinas Pendidikan Provinsi Jawa Tengah Nomor 423.5/15322 Tahun 2014 tentang Pelaksanaan Kurikulum 2013 Muatan Lokal Bahasa Jawa di Provinsi Jawa Tengah.

[10] Surat Instruksi Bupati Nomor 431/1324/023/2014 tentang Penggunaan Bahasa Jawa untuk Komunikasi Lisan di Lingkungan Pemkab Sragen.

[11] Zentz, L. (2015). Moving languages: Syncretism and shift in Central Java. Tilburg Papers Culture Studies, 141, 1-26. 